\title{
Egypt Education System: A Monocultural Education in a Multicultural Society
}

\author{
Monir Atta-Alla, Ph. D \\ Eastern University, USA \\ E-mail: mattaall@eastern.edu
}

Accepted: October 11, 2012 Published: November 20, 2012

Doi:10.5296/jsr.v3i2.2645 URL: http://dx.doi.org/10.5296/jsr.v3i2.2645

\begin{abstract}
Egyptian minority students are stereotyped by Egyptian majority students, teachers, and administrators based on an assumed range of activities, characteristics, or behaviors. They are discriminated against and treated less favorably on the grounds of their religious background. This article explores the difficult positions that teachers and administrators may encounter in ethnically, culturally, and religiously diverse settings. It investigates how stereotyping Egyptian Christians as a religious minority in Egypt causes them to face discrimination on a daily basis. It also discusses how the discriminatory educational practices and policies, curriculum and textbook, and school environment in Egypt have resulted in a monoculture education system in a multicultural society.
\end{abstract}

Keywords: Multicultural Education, Stereotyping, Discriminatory Educational practices, School Environment, Curriculum and Textbooks

\section{Introduction}

In the twenty first century, most countries and nations are becoming multiethnic, multicultural, or multireligious. Instead of using the cultural, religious, or racial human diversity to enrich human society, people often misuse this richness to fuel hatred and intolerance. The last century has witnessed serious and devastating expressions of racism, discrimination, and related intolerance. In some countries, ethnic and religious minorities are subjected to government, group, and/or individual prejudice, injustice, and discrimination. Dovidio and Gaertner (1999) defined prejudice as "an unfair negative attitude toward a social group or a member of that group" (p.101). According to Kottak (2000), prejudice means looking down on "a group because of its assumed behavior, values, abilities, or attributes" ( $p$. 124). In contrast, stereotypes are overgeneralizations about a group or its members that are factually incorrect and inordinately rigid (Dovidio \& Gaertner, 1999). Stereotypes are unfavorable fixed ideas about what members of a group are like (Kottak, 2000). Discrimination is usually the actions and behaviors that are taken based upon prejudice 
and/or stereotyping. Fiske (2004) states that the difference between prejudice and discrimination is a matter of degrees between what an individual feels and what an individual thinks. According to Kottak (2000), the historical, social, economic, political, cultural, or religious injustice, discrimination, prejudice, and stereotyping minority groups are the main sources of ethnic conflicts around the world. Morris (2011) indicates that stereotyping for various reasons continues to be alive and is seemingly engrained in the human psyche.

The immense cultural mix of Egypt population makes it a unique Middle Eastern Country. The culture of modern Egypt includes a variety of live traditions that remain from the time of the Pharaohs, as well as those that were brought in by the many invaders throughout the centuries. Atta-Alla (2008) states, "Contemporary Egyptian culture is a mixture of a multitude of elements, shaped by the progression of historical events, which has contributed to the development of Egypt's current atmosphere" (p.114). The name "Egypt" is derived from the Greek word Aegyptos. For several centuries, Egypt was essentially a Christian country. Atta-Alla (2008) states that when the Arabs invaded Egypt in 641 AD, they called the Egyptians 'Qipt', 'Gibt', or 'Gypt'. They use the word Qipt, Gibt, or Gypt to mean both Egyptians and Christians. The modern use of the term 'Copts' describes Egyptian Christians who are members of the Coptic Orthodox Church, which was founded by St. Mark, the Evangelist of Alexandria around 43 A.D. The Coptic Orthodox Church, which is also known as the Church of Alexandria, is one of the four oldest apostolic churches in the world. The other churches are the Church of Jerusalem, the Church of Rome, and the Church of Antioch. Although the Muslim conquest to Egypt brought a new force, it took Muslims a few centuries to become a majority.

Although the Egyptians are a fairly homogeneous people of Hermitic origin, one can observe two different types of minorities. The first type of minorities is the religious minority represented in the Copts (Egyptian Christians) who belong to the Coptic Orthodox Church, the historic church of Egypt. Catholic, Evangelical, Protestant, Maronite, Greek Orthodox, and Greek Catholic are Christian minorities within the Coptic minority. There are also a few Jewish families and Bahai's. The second type of minorities is the ethnic minorities that include a small number of Bedouin Arab and Nubians. Goujon, Alkitkat, and Prommer (2007) indicate that the total population of Egypt increased from 22 million in 1950 to 75 million in 2007, and is likely to increase to above 120 million by 2050. The total population of Egypt in 2010 was over 80 million and Copts (Egyptian Christians) form almost 22\% to 25\% of the population. Although Copts are integrated into the body of the Egyptian nation, they can be easily distinguished. Most Christian men and women have a cross tattooed on the inside of the right wrist. Names also distinguish Muslims from Christians. Muslims have Arab and Islamic names and Christians have biblical or secular Egyptian names.

Copts, who are the indigenous people of Egypt Egyptian, have their own ways of thinking, believing, feeling, and acting that constitute their unique minority group's culture. Their culture is a major component of their identities within a framework of their social cohesion. Egypt is one of the countries where Copts (Egyptian Christians), as a religious minority 
group, face continued social, economic, political, cultural, educational, and religious stereotyping and discrimination. Fundamental Muslims officially and unofficially do not tolerate other minorities, particularly Christians and Jews and persecute them from time to time. An Islamist revivalist movement in Egypt has challenged the full political and economic participation of certain minority groups, including Christians (Shukrallah, 1994). Although Egypt is a pluralistic society that should allow all minority groups to proclaim their identities without coming into conflict with the majority population, the Egyptian government and the radical Egyptian Muslims generally neglect and marginalize the Coptic culture. They consider it the culture of a minority group that lives in the shadow of the Muslim majority population who have different and dominant cultural ideology. Consequently, Copts are subject to continued economic, cultural, communication, and educational policies that undermine the bases of their existence. These unjust and discriminatory policies and practices nullify and impair the Egyptian Christians' recognition, enjoyment, and exercise of their human rights and fundamental freedoms in the political, economic, social, cultural, educational and other dimensions of public life in their country. Such policies and practices are becoming social stressors that have negative impacts on Copts' mental and physical health. A growing body of research has suggested that "the psychological and physiological correlates and consequences of discrimination are similar to those of other psychosocial stressors" (Guyll, Matthews, \& Bromberger, 2001; Meyer, 2003a; Schulz et al., 2000; Williams, Spencer, \& Jackson, 1999). Research findings also indicate that discrimination against groups of marginalized diverse student populations including gender, social class, religion, disabilities, sexual orientation, disabilities, and immigration negatively influence their academic achievement (Banks \& Banks, 2010; Gay, 2010; Taylor \& Whittaker, 2009). The following sections describe how the discriminatory educational practices and policies have resulted in a monocultural education system in Egypt.

\section{Discriminatory Policies}

The ultimate aim of education in multicultural, multiethnic, and multireligious societies should be the creation of effective dialogue and the promotion of peaceful coexistence and positive interaction among the different cultural, ethnic, and religious groups. Education should be responsive to the specific needs of both the mainstream students and the minority students. It should equip all groups with the necessary knowledge and skills that enable them to participate actively and fully in their larger societies. According to Garderen \& Whittaker (2006), one of multicultural education goals is to afford all students with the skills, attitudes and knowledge needed to function within their ethnic culture, the mainstream culture, and within and across other ethnic cultures. The Egyptian government created many discriminatory policies and legislations and the Egyptian constitution has laid down the foundation of an exclusive Islamic legislative interpretation of laws. According to Starrett (1998), Sadat renewed the commitment to Islamic symbols and made them part of government policy to steer the nation from the Soviet into the American military and economic spheres. President Sadat also released the Islamic activists from the Muslim Brotherhood, imprisoned during the 1950s and 1960s and encouraged the formation of 
Islamic student organizations at the Egyptian universities to vie for influence with leftist groups. The new Constitution of Egypt, drafted at the order of the president Sadat in 1971, specifically mandated religious education in the schools, and specified that the Islamic shari'a was to be a major source-later to become the major source-of legislation. As a result, radical Egyptian Muslims in the society and the judiciary relegate the other religious minority groups in general and the Christian minority group in particular into a "lesser" status of citizenship. Consequently, the rights and freedoms of religious minorities such as Coptic (Christian) minority, Jewish minority, and Bahai's minorities are systemically and officially violated. The discriminatory policies in all facets of life including education against minorities, particularly Christians in Egypt have resulted in mass exodus. Heikal (2000) states, "There is a migration phenomenon among Copts that we should not ignore. We should neither overlook its causes, even if they were psychological "(p. 14).

Education in Egypt, as a multicultural, multiethnic, and multireligious society, is supposed to encourage a greater openness towards others who have different cultural, social, ethnic, racial, or religious backgrounds. It should foster harmonious co-existence within and between multicultural, multiethnic, and multireligious groups. On the contrary, since the dominant culture in modern Egypt is the culture of the Muslim majority, the ultimate aim of education in Egypt has become the promotion of a singular interpretation of the Islamic society. Starrett (1998) stresses that the nationwide food riots in January of 1977 enhanced religious education as one of the solutions president Sadat called for to restore political stability. Gradually, education in Egypt became Islamic. It reflects the Islamic nature of the state. This is clearly reflected in the education policies, curriculum, pedagogy, school system, school atmosphere, etc. In its most literal sense, Islamic education can refer to efforts by the Muslim community to educate its own, to pass along the heritage of Islamic knowledge, first and foremost through its primary sources, the Qur'an and the Sunnah. This education of Muslims might take place in mosques, schools or universities, and other organizations established by Muslims over the centuries (Douglass \& Shaikh, 2004). In the field of education, Egyptian Muslims use the term "Islamic education" to refer to what relates to Islamic teachings or institutions and to elevate the Islamic cultural expressions to the position of normative or consummate institutions or practices. Despite this fact, many Egyptian Muslim educational policy makers, officials, textbook writers, administrators, and teachers imply that Islamic education omits secular knowledge in favor of religious beliefs. Some of them even go to the extreme and try to limit it to rigid transmittal of 1400 year-old life ways from ancient Arabia.

In addition to the K-12 public schools that include both Muslims and Christian students, there is another public education system that includes Muslim students only. This education system is called the "Azharite education system" that is supervised by the Supreme Council of the Al-Azhar Institution and is independent from the Ministry of Education. But the Al-Azhar Institution itself is placed under government supervision, and its educational system is actually supervised by the Egyptian Prime Minister. The Al-Azhar schools are named "Institutes" and include primary, preparatory, secondary, and university levels. All schools in all phases teach non-religious subjects, to a certain degree, although not as intensively as the 
state schools. The bulk of the curriculum, however, consists of religious subjects. All the students are Muslim, and males and females are separated in all phases. The Azharite schools are spread all over the country; especially in rural areas. The graduates of the Azharite secondary schools are eligible to continue their studies at the Al-Azhar University only.

Starting from January 1971, Ministry of Education in Egypt has been working on Islamizing the Egyptian Education System. "An individual's belief system is closely interwoven with his or her identity and understanding of the world and is therefore extremely difficult to change" (Szpara \& Wylie, 2005, p. 808). Gay (2010) emphasizes the profound effect of educator's beliefs and the ability of these beliefs to shape teaching. The radical Muslim policy makers used their religious beliefs to create and use policies, general rules, and practices that do not allow Christian students and teachers to practice their cultural and religious differences. Such discriminatory policies and practices include both direct and indirect discrimination against Christian students and teachers, a lack of proactive measures to prevent discrimination against Christian students and teachers, a lack of professional expertise or training in dealing with diversity, and a lack of workable facilities for consulting and listening to Christian students and teachers as a religious minority group. Issac (2007) discusses how the educational system in Egypt has been Islamized. Many of the Egyptian Ministry of Education officials practice both direct and indirect racism against Christian students by using practices and policies that actually have a discriminatory impact such as forcing Christian students to go to school on Sundays, neglecting their history in the curriculum, and holding examinations during Christian Holidays, feasts, and celebrations, forcing Christian students to study texts from the Quran and the sayings of the Islamic prophet and recite Islamic songs and slogans, and including Islamic names in most content area textbooks.

\section{Curriculum and Textbooks}

In any diverse society, the curriculum is one of the most significant factors affecting the success of diverse learners in school. The curriculum should be used to equip students with the knowledge, understanding, and skills to participate actively in their society and to be responsible citizens. Therefore, school curriculum should make room at all levels for teaching about different values, views, and approaches. (Reid, 1995) states that providing a curriculum, which reflects the experiences of a diverse population, also helps in retaining traditionally underrepresented student populations by providing a curriculum which is culturally relevant and responsive. Zambo and Brozo (2009) emphasize that students need to encounter images to which they can relate; they need to see people like themselves demonstrating "values worth imitating and characters worth modeling" (p. 9). Literature also indicates that students' motivation levels and academic success are enhanced when they see themselves and their personal experiences reflected in texts and images (Gangi, 2008). The Egyptian educational system is geared to form a student who might academically be brilliant but very conservative from the social point of view. Egypt has national k-12 curriculum mandated by the Ministry of Education to be taught in all schools. The national k-12 curriculum in Egypt is not culturally or religiously pluralistic. It is not culturally or religiously responsive to Christian 
students as a religious minority. It capitalizes only on the Muslim students' cultural and religious background and always attempts to override and negate Christian students' cultural and religious background. It is not an inclusive curriculum that can help promote intergroup harmony and reduce conflict between Christian students as a minority and Muslim students as a majority. The k-12 curriculum is intentionally planned to abolish the Christian identity from Egypt by mainly focusing on the Islamic images, history, culture, traditions, values, and characters. These images influence students' view of themselves and others (Al-Hazza \& Bucher, 2008; Gates \& Mark, 2006; Hall, 2008; Stallworth, Gibbons, \& Fauber, 2006).

Although Egyptian teachers are free to choose modes of teaching, the school curricula have prescribed content and forms of assessment. Typically, the textbooks that reflect the national curriculum are the main source of educational materials. Each textbook comprises a body of lessons that is ideally a synthesis of the best of what decision-makers and authors agree to be worthwhile and necessary for the learning process in each school subject. This limits any flexibility for decision-making either by the schools or individual classroom teachers. It also overlooks the cultural and religious diversity of the learners, which are important factors in culturally and religiously relevant pedagogy. According to a report posted to Jihad Watch website on April 6, 2004, Egyptian textbooks required for state schools exalt Islamic war (Jihad). The majority of the textbooks reflect the Islamic nature of the society. Al-Ashmawi (1995) states that history textbooks in the Arab Islamic countries, including Egypt glorify and embellish the scientific discoveries of Arab Muslim scholars and philosophers, praise the golden age of Islam, and focus on the difference between the enlightenment of the golden age of Islam and the darkness in which westerners were living in during the Middle Ages. Reviewing and analyzing the complete edition of many Egyptian textbooks especially social studies for preparatory school and history for the secondary school textbooks, which were in use in the school year 2001/02 which are mandatory in public schools as well as in private schools, Reiss (2003) found that the existence of indigenous Christians in the past and present is neglected and ignored totally. Egyptian Christianity is portrayed mainly as a national movement of resistance against Rome and Byzanz. The textbooks avoid any national and religious identities conflict. The continuing contributions of Christians to the Egyptian society and their life in the following centuries are totally ignored.

Egyptian textbooks which are considered the main source of educational materials are full of discriminatory evidences against minority group students and reflect the monocultural and nonreligious education system in Egypt. For example, the Egyptian social studies curriculum and textbooks are not integrated with inputs on both Christian and Muslim students. On the contrary, they offer to the students a broader knowledge in touch with the Islamic cultural heritage. The main focus is on the Islamic history and the wars and victories of Mohammed, the Prophet of Islam. The history textbooks deliberately neglect whatever Coptic (e.g. the Coptic era, Coptic monasteries, ancient Coptic sites, churches, etc.). The Geography textbooks also deliberately neglect the Coptic Egypt. The Egyptian science textbooks don't include the contributions Christians made to science, and if it happens it is just the name of the scientist without details. The Egyptian Mathematics textbooks always include Muslim 
names. K-12 Christian students are forced to memorize the Quran and take exams on it through the lessons of the Arabic language textbooks, which are full of discrimination against Christian students and their religious beliefs. Each lesson starts with a Quranic verse. Some lessons are suras (chapters) from the Quran, the Muslims' Holy Book. All names of people, places, incidents, etc. are Islamic names. The girls and women's pictures are Islamic; they are wearing the Islamic dress.

\section{School Environment}

Since Egypt has become an Arab Muslim country, the daily educational practices at schools are made to reflect the nature and goals of this Islamic nation. The weekly school holiday is Friday, which is a sacred Islamic day. Sunday is a regular school day and Christian students have to go to school on Sundays. The school year calendar is designed to reflect the Islamic holidays, celebrations and occasions. It completely neglects Christian holidays. The school day starts with the Quran and Christian students are obliged to listen to the Quranic and Hadith (Islam Prophet's speeches and sayings) readings and repeat them. In the classroom, both the Islamic Basmala (Besm Allah Al -Rahman Al Raheem whish is "In the name of God, the Most Compassionate, and the Most Merciful") as well as the Islamic date is permanently written on the board and all students have to use it. Starrett (1998) states that in the chapter on "character", in his classic Manners and Customs of the Modern Egyptians, first published in 1836, Edward Lane wrote, "children in Egypt are often taught, at school, a regular set of curses to denounce upon the persons and property of Christians, Jews, and all other unbelievers in the religion of Mohammad." The following is an example of such curses. "O God, destroy the infidels and polytheists, thine enemies, the enemies of the religion. O God, make their children orphans, and defile their abodes, and cause their feet to slip, and give them and their families and their households and their women and their children and their relations by marriage and their brothers and their friends and their possessions and their race and their wealth and their lands as booty to the Muslims.

Schools should create a supportive, positive, and learning stimulating atmosphere and environment to students of all cultural and religious backgrounds. It should develop and promote a positive sense of self-esteem of students of all backgrounds as individuals and members of certain cultural, ethnic, or religious minority groups. Egyptian schools do the opposite to the students belonging to cultural, ethnic, or religious minority groups who are in danger of developing a low sense of self-esteem due to the injustice and discriminatory school environment. The Egyptian school environment increasingly promotes racism and discrimination against minority groups in general and Christian students in particular. Christian students are stereotyped by Muslim students, teachers, and administrators based on an assumed range of activities, characteristics, or behaviors. They are discriminated against treated less favorably on the grounds of their cultural and religious background. Christian students are often assigned inferior status in the Egyptian public school structure. They also experience social segregation that excludes them from meaningful interactions with the Muslim students as the dominant group in schools. In most cases, Christian students accept 
such negative stereotypes, prejudice and injustice. Landt (2011) stresses that students may accept prejudice and injustice when they do not recognize negative stereotypes which are reinforced by what they encounter. Segregated by Muslim students, teachers, and school administrators, Christian students even re-segregate themselves. Researchers in multiethnic and multicultural schools have found that students tend to re-segregate themselves. For instance, ethnic groups may define particular areas of the school as "their territory" (Romo \& Falbo, 1996).

In the Egyptian K-12 schools, Muslim students, teachers, and administrators are permitted to speak freely about Islam to Christian students, teachers, and administrators and actively to encourage conversion to Islam. Christians, however, are not permitted to proselytize Muslims. Christian students are arrested and detained for any peaceful, private religious speech and expression to Muslims. The Egyptian school policies and daily practices also contribute to the segregation of Christian students. During religious education lessons which are mandatory, Muslim students stay in the classrooms and Christian students get out to the playground. While the Egyptian ministry of education appoints Muslim teachers (usually graduates of Al-Azhar University) to teach religious education lessons to Muslim students, the teaching of religious education lessons to Christian students is usually delegated to any Christian teacher at the school, who usually finds himself/herself reluctant and unprepared to teach such lessons. Many Muslim teachers and school administrators exclude Christian students from academic activities, sports activities, friendship cliques, social activities and limit their status and popularity. This leads to racial and ethnic conflicts, which establish an alternative sense of identity within the school. According to Hammack (2008), identity is scripted in and through social interaction and social practice. Schofield (1995) states that when teachers and administrators segregate students to create racially or ethnically homogeneous groups, the classes often magnify already existing stereotypes and discrimination. Additionally, ethnic boundaries between Christian and Muslim students in the Egyptian K-12 schools become more distinct when students experience the divisions between "them" and "us". "Them" is always the non-Muslims.

\section{Implications and Recommendations}

To maintain stability and positive relationships in multiethnic and multi-religious classrooms, students from different ethnic, cultural, and religious backgrounds need to feel that they are accepted and that they belong. There is a growing need to address multiculturalism and diversity awareness in today's classrooms (Riskowski \& Olbricht, 2010). Interventions to reduce prejudice and discrimination are also essential. According to Parrish and Van Berschot (2010), "the growing multicultural nature of education and training environments makes it critical that instructors...develop skills to deliver culturally sensitive and culturally adaptive instruction" (p.1). In the context of the analysis of the discriminatory policies and practices in the Egyptian educational system and to respond to the many calls for protecting human rights and eliminating discrimination and racism, this section of the paper discusses some suggested educational approaches and strategies to promote multicultural education and diversity 
responsive curriculum and school environment as well as enhance effective culturally relevant teaching in the Egyptian K-12 public schools. Dunn, Kirova, Cooley, and Ogilvie (2009) stress that it is important for teacher education programs to continue to explore innovative ways to infuse intercultural inquiry into teacher preparation to broaden student teachers' experiences with diversity.

To reduce discrimination against Christian students, Egypt ministry of education can adopt an educational approach, a vicarious approach, and an intergroup contacts approach (McLemore \& Romo, 1998). By adopting an educational approach, Egypt ministry of education should expose students and teachers to accurate information about other groups to allow them to learn about intergroup similarities and differences. When individuals have accurate information, they are less likely to accept stereotypes and to be prejudiced (Hewstone \& Brown, 1986; Sue, 1995). As students and teachers gain knowledge about other groups and their histories, they will be more likely to respect members of those groups and cooperate with them. According to Pearl (1997), drawing attention to the processes of discrimination, engaging actively in team building, and consulting continuously with students, all help develop a new culture of tolerance and understanding. Through adopting the vicarious experience approach, the Egyptian educational curriculum should include texts, films, plays, biographies, novels, and other ways of presenting members of all groups in a respectful way. Exposure to such materials will help students recognize the commonalities of all groups and reduce their tendency to draw sharp boundaries between "them" and "us." When adopting an Intergroup contacts approach, teachers and school administrators can improve intergroup relations by having students from both majority and minority groups participate in joint activities. When people do things together, they have opportunities to judge people on their own merits rather than on stereotypes. These contacts are most successful if the people involved are of equal social status, are working cooperatively on something, if their activity is supported by people in positions of authority, and if the activity involves a high level of intimacy (McLemore \& Romo, 1998).

Egypt ministry of education can employ several strategic, motivational, and confrontational means to change discriminatory attitude and behavior and to enhance diversity responsive curriculum, school environment, and effective culturally relevant teaching in Egyptian K-12 public schools. Egyptian teachers should maximize student interest, abilities, strengths and passions by adhering to a framework which allows every student to feel valued and develop meaningful understanding (Vermette, 2009). They should expose all students to cultures dissimilar from their own to enable them to "understand and learn to respect cultural differences while recognizing human universals" (Cai, 2002, p. 126). They should make students learning meaningful by making the instructional material highly relevant and transferrable to students' lives (Ladson-Billings, 2009). They should build diverse, inter-group relations among students to promote dialogue and friendships between students of different racial groups (Moses \& Banh, 2010). Egyptian teachers should use culturally relevant pedagogy which recognizes that all students have strengths and talents, and calls for multiple diverse opportunities for students to demonstrate knowledge of subject matters 
(Jones, Jones, \& Vermette, 2011); to meet the academic and social needs of culturally diverse students (Gay, 2000; Ladson-Billings, 2001); and promote a flexible use of students 'local and global culture Ladson-Billings (2006). Using multicultural literature in the classroom is one of the culturally relevant pedagogy tools that can increase respect for differences and develop recognition of the common characteristics that all cultures share (Smolen, Collins, \& Still, 2008). According to Sirin, Rogers-Sirin, and Collins (2010), the effort to increase and improve cultural awareness and expand culturally responsive pedagogy carries a sense of urgency. Egyptian teachers should use the method of "teaching through others", or "dialogical methods of instruction" to help transform schools into communities of learners who acquire knowledge while practicing global citizenship (Ligorio, 2010). Egyptian teachers should have the ability to interrupt and deconstruct prejudice and racism to establish and maintain meaningful relationships with children of diverse groups; they must make sure they do not let issues such as prejudice and/or racism gain access to their classrooms Pica-Smith (2009). They should strengthen minority group students' identity by creating accepting and supportive classroom environment (Coburn, 2006; Hammack, 2008). In assessing their students' performance, Egyptian teachers should largely base their judgment of students' performance and achievement on their belief system and the understanding of their role in the education system and in society (Vermette, 2009).

\section{Conclusion}

It is essential to prepare educational policy makers, teacher educators, school administrators, teachers, and students for the increasing diversity in the classroom. The insensitivity of the educational policies, rules, practices, school culture, and curriculum in Egypt to the culture and needs of students from minority groups, results in creative tension and negative relations between Muslim teachers and non-Muslim students and between Muslim students and their non-Muslim peers. This paper argues that the current Egyptian education system is not inclusive of the cultural, religious, and ethnic minority groups in general and the Egyptian Christians in particular. The inequality in the Egyptian society between Christians and Muslims in general and in the education system in particular, including educational policies, curricula and textbooks, school environment, and educational opportunities and outcomes continue to grow. This unjust, discriminatory, and prejudice attitude results in widening the gap and uplifting it to the crisis proportions between Muslim and Christian students. The discrimination against Christian students at every level of the education system in Egypt disappoints and frustrates a larger proportion of Christian students as they progress through the school system.

\section{References}

Al-Ashmawi, F. (1995).The image of the other in history textbooks in some Mediterranean countries (Spain, France, Greece, Egypt, Jordan, Lebanon, Tunisia). Islam Today, 13.

Al-Hazza, T. C., \& Bucher, K. T. (2008). Building Arab Americans' cultural identity and acceptance with children's literature. The Reading Teacher, 62 (3), 210-219.

Atta-Alla, M. (2008). Contemporary Egyptian family. In T. Maundeni, L. L. Levers, \& G. 
Jacques (Eds.), Changing family systems: A global perspective (pp. 114-126). Gaborone, Botswana: Bay Publishers.

Banks, J. A., \& Banks, C. A. (2010). Multicultual education: Issues and perspectives ( $7^{\text {th }}$ Ed.). Hoboken, N.J.: John Wiley \& Sons, Inc.

Cai, M. (2002). Multicultural literature for children and young adults: Reflections on critical issues. Westport, CT: Greenwood Press.

Coburn, C. E. (2006). Framing the problem of reading instruction: Using frame analysis to uncover the microprocesses of policy implementation. American Educational Research Journal, 43(3), 343-379.

Douglass, Susan L. \& Shaikh, Munir A. (2004). Defining Islamic education: Differentiation and applications. Current Issues in Comparative Education, 7(1), 5-18.

Dovidio, J., \& Gaertner, S. (1999, August). Reducing prejudice: Combating intergroup biases. Current Directions in Psychological Science, 8(4), 101-105.

Dunn, W., Kirova, A., Cooley, M., \& Ogilvie, G. (2009). Fostering intercultural inquiry in subject-area curriculum courses. Canadian Journal of Education, 32. 533-557.

Fisk, S. (2004). Social beings: A core motives approach to social psychology. Hoboken, NJ: John Wiley \& Sons, Inc.

Gangi, J. M. (2008). The unbearable whiteness of literacy instruction: Realizing the implications of the proficient reader research. Multicultural Review, 30-38.

Garderen, D. \& Whittaker, C. (2006). Planning differentiated, multicultural instruction for higher education classroom. Teaching Exceptional Youngsters, 38 (3), 12- 22.

Gates, P. S., \& Mark, D. L. (2006). Cultural journeys: Multicultural literature for children and young adults. Lanham, Maryland: The Scarcrow Press, Inc.

Gay, G. (2010). Acting on beliefs in teacher education for cultural diversity. Journal of Teacher Education, 61(1-2), 143-152. doi: 10.1177/ 0022487109347320

Gay, G. (2000). Culturally responsive teaching: Theory, research, and practice. New York: Teachers College.

Goujon, A., Alkitkat, H., Lutz, W., \& Prommer, I. (2007). Population and human capital growth in Egypt: Projections for governorates to 2051. Project Report. Cairo: Demographic Center.

Guyll, M., Matthews, K. A., \& Bromberger, J. T. (2001). Discrimination and unfair treatment: Relationship to cardiovascular reactivity among African American and European American women. Health Psychology, 20, 315-325.

Hall, K. W. (2008). The importance of including culturally authentic literature. Young Children, 80-86.

Hammack, P. L. (2008). Narrative and the cultural psychology of identity. Personality and Social Psychology Review, 12(3), 222-247. doi: 10.1177/ 1088868308316892

Heikal, M. H. (2000). Al-Koutoub: Weghat Nazzar; i.e. Books: Viewpoints. Cairo.

Hewstone, M., \& Brown, R. (1986). Contact and conflict in intergroup encounters. New York: Blackwell.

Issac, K. F. (2007). "Islamization of the educational system in Egypt. Paper presented in the Coptic Assembly of America." Retrieved from http://www.copticassembly.org/ showart.php?main_id=620 
Jihad Watch (2010). "Egyptian textbooks exalt jihad, demean Jews." Retrieved from http://www.jihadwatch.org/2004/04/ egyptian-textbooks-exalt -jihaddemean-jews.html

Jones, K. A., Jones, J. L., \& Vermette, P. J. (2011). Reaching and teaching all learners: An integration of the tenets of culturally relevant teaching and the engaging framework. The Journal of Multiculturalism in Education, 7(2), 1-14.

Kottak, C. P. (2000). Anthropology: The exploration of human diversity. ( ${ }^{\text {th }}$ Ed.). Boston: McGraw-Hill.

Ladson-Billings, G. (2001). Crossing over to Canaan: The journey of new teachers in diverse classrooms. San Francisco: Jossey-Bass.

Ladson-Billings, G. (2006). Education research in the public interest: Social justice, action, and policy. New York: Teachers College Press.

Ladson-Billings, G. (2009). The dreamkeepers: Successful teachers of African American children. San Francisco: Jossey-Bass.

Landt, S. M. (December, 2011). Integration of multicultural literature in primary grade language arts curriculum. The Journal of Multiculturalism in Education, 7(2), 1-27.

Ligorio, M.B. (2010). Dialogical relationship between identity and learning. Culture \& Psychology, 16 (1), 93-106.

McLemore, S. D., \& Romo, H. D. (1998). Racial and ethnic relations in America. (5 $5^{\text {th }}$ Ed.). Boston: Allyn and Bacon.

Meyer, I. H. (2003a). Prejudice, social stress, and mental health in lesbian, gay, and bisexual populations: Conceptual issues and research evidence. Psychological Bulletin, 129(5), 674-697.

Morris, J. J. (2011). The stereotyping of American Indians: Where do we currently stand at the university level? The Journal of Multiculturalism in Education, 7(3), 1-12.

Moses, Y. \& Banh, J. (2010). Diversity literature review in higher education: The next research agenda. The Journal of Multiculturalism in Education, 6 (3), 1-33.

Parrish, P., \& VanBerschot, J. (2010). Cultural dimensions of learning: Addressing the challenges of multicultural instruction. International Review of Research in Open and Distance Learning, 11, 1-16.

Pearl, A. (1997). Democratic education as an alternative to deficit thinking. In R. R.Valencia (Ed.), The evolution of deficit thinking: Educational thought and practice (pp. 211-241). London; Washington, D.C.: Falmer Press.

Pica-Smith, C. (2009). Children speak about interethnic and interracial friendships in the classroom: Lessons for teachers. Multicultural Education, 17(1), 38-46

Reid, G. (1995). On Technology, curricula, and ethnic diversity: Mapping the route to the new millennium. Community College Journal, 65 (5), 18-24.

Reiss, W. (2003). The portrayal of Christianity in Egyptian textbooks main findings and conclusions of investigations. Germany: Watson institute for international studies.

Riskowski, J. \& Olbricht, G. (2010). Student views of diversity: A multicultural mathematics activity. Viewing transformation during the middle school years. Multicultural Education, 17(2), 2-12.

Romo, H. D., \& Falbo, T. (1996). Latino high school graduation: Defying the odds. Austin: 
University of Texas Press.

Schofield, J. W. (1995). Improving intergroup relations among students. In J. A. Banks and Ch. A. McGee Banks (Eds.), Handbook of research on multicultural education (pp. 635-46). New York: Macmillan Publishing.

Schulz, A., Williams, D. R., Israel, B., Becker, A., Parker, E., James, S. A., et al. (2000). Unfair treatment, neighborhood effects, and mental health in the Detroit metropolitan area. Journal of Health and Social Behavior, 41, 314-332.

Shukrallah, H. (1994). The impact of the Islamic movement in Egypt. Feminist Review, 47, 15-32.

Sirin, S. R., Rogers-Sirin, L., \& Collins, B. A. (2010). A measure of cultural competence as an ethical responsibility: Quick-Racial and Ethical Sensitivity Test. Journal of Moral Education, 39(1), 49-64. doi: 10.1080/03057240903528675

Smolen, L. A., Collins, L.J., \& Still, K. L.(2008). Enhancing cultural understanding and respect with multicultural text sets in the K-8 classroom. Ohio Journal of English Language Arts, 48 (2), 18-29.

Stallworth, J., Gibbons, L., \& Fauber, L. (2006). It's not on the list: An exploration of teachers' perspectives on using multicultural literature. Journal of Adolescent \& Adult Literacy, 49 (8), 478-489.

Starrett, Gregory (1998.). Putting Islam to work: Education, politics, and religious transformation in Egypt. Berkeley: University of California Press.

Sue, D. W. (1995). Toward a theory of multicultural counseling and therapy. In J. A. Banks and Ch. A. McGee Banks (Eds.), Handbook of research on multicultural education (pp. 647-59). New York: Macmillan Publishing.

Szpara, M. Y., \& Wylie, E. C. (2005). National board for professional teaching standards assessor training: Impact of bias reduction exercises. Teachers College Record 107(4), 803-841. Retrieved January 24, 2012 from http://www.tcrecord.org/

Taylor, L. S., \& Whittaker, C. R. (2009). Bridging multiple worlds: Case studies of diverse educational communities. Bostom: Allyn and Bacon.

Vermette, P. J. (2009). Engaging teens in their own learning: 8 keys to student success. Larchmont, New York: Eye-On-Education

Williams, D. R., Spencer, M. S., \& Jackson, J. S. (1999). Race, stress, and physical health: The role of group identity. In R. Contrada, and R. Ashmore (Ed.), Self, social identity and physical health: Interdisciplinary explorations (Vol. 2, pp. 71-100). New York: Oxford University Press.

Zambo, D., \& Brozo, W. G. (2009). Bright beginnings for boys: Engaging young boys in active literacy. New York: International Reading Association. 